\title{
Development of a fluoride-responsive amide bond cleavage device that is potentially applicable to a traceable linker
}

\author{
Jun Yamamoto, ${ }^{\mathrm{a}, \dagger}$ Nami Maeda, ${ }^{\mathrm{a}, \dagger}$ Chiaki Komiya, ${ }^{\mathrm{a}}$ Tomohiro Tanaka, ${ }^{\mathrm{b}}$ Masaya Denda, ${ }^{\mathrm{a}}$ Koji Ebisuno, ${ }^{\mathrm{a}}$ Wataru \\ Nomura, ${ }^{\mathrm{b}}$ Hirokazu Tamamura, ${ }^{\mathrm{b}}$ Youichi Sato, ${ }^{\mathrm{c}}$ Aiko Yamauchi, ${ }^{\mathrm{c}}$ Akira Shigenaga ${ }^{\mathrm{a}, \mathrm{d}, *}$ and Akira Otaka ${ }^{\mathrm{a}, *}$ \\ ${ }^{a}$ Department of Bioorganic Synthetic Chemistry, Institute of Health Biosciences and Graduate School of Pharmaceutical Sciences, The University of Tokushima, \\ Shomachi, Tokushima 770-8505, Japan \\ ${ }^{b}$ Institute of Biomaterials and Bioengineering, Tokyo Medical and Dental University, Chiyoda-ku, Tokyo 101-0062, Japan \\ ${ }^{c}$ Department of Pharmaceutical Information Science, Institute of Health Biosciences and Graduate School of Pharmaceutical Sciences, The University of \\ Tokushima, Shomachi, Tokushima 770-8505, Japan \\ ${ }^{d} J S T$, PRESTO, 4-1-8 Honcho, Kawaguchi, Saitama, 332-0012, Japan
}

${ }^{\dagger}$ These authors contributed equally to this work.

\section{ARTICLE INFO ABSTRACT}

Article history:

Received

Received in revised form

Accepted

Available online

Keywords:

Cleavable linker

Fluoride-responsive

Traceable linker

Stimulus-responsive amino acid

\begin{abstract}
A fluoride-responsive (FR) amino acid that induces amide bond cleavage upon the addition of a fluoride was developed, and it was applied to a FR traceable linker. By the use of an alkyne-containing peptide as a model of an alkynylatd target protein of a bioactive compound, introduction of the FR traceable linker onto the peptide was achieved. Subsequent fluoride induced cleavage of the linker followed by labeling of the released peptide derivative was also conducted to examine the potential applicability of the FR traceable linker to the enrichment and labeling of alkynylated target molecules.
\end{abstract}

2009 Elsevier Ltd. All rights reserved.

\section{Introduction}

A wide variety of molecules including natural products, peptides, and synthetic small compounds exhibit their biological activities through specific interactions with target biomacromolecules. Proteins including enzymes, receptors, and ion channels represent the major group of these targets. Identification of unknown protein targets that interact with biologically active ligands has become indispensable in the fields of chemical biology and drug development; however, this research approach is time-consuming and laborious. The target identification comprises a sequence of processes: (1) fishing a target using a biologically active ligand as bait; (2) enrichment of the hooked target; and (3) sequence analysis of the target by Edman degradation or mass spectrometry (MS). ${ }^{1}$ For the first step, photo-affinity labeling which allows bait to be covalently bounded to the corresponding target upon photo-irradiation has significant use, because of the potential applicability to low affinity ligand-target pairs. ${ }^{1 \mathrm{a}, \mathrm{b}, 2}$ The hooked target is then linked with a biotinylated linker molecule for facile purification by streptavidin beads using the biotin-streptavidin interaction. ${ }^{1,3}$ The immobilized target is subsequently released from the beads for

* Corresponding authors. Tel.: +81-88-633-9534; fax: +81-88-6339505; e-mail: shigenaga.akira@tokushima-u.ac.jp (A. Shigenaga), aotaka@tokushima-u.ac.jp (A. Otaka)

(C) 2014. This manuscript version is made available under the Elsevier user license

http://www.elsevier.com/open-access/userlicense/1.0/ sequence analysis by attenuating the biotin-streptavidin interaction. The high affinity of the biotin-streptavidin interaction $\left(K_{\mathrm{d}}=10^{-15} \mathrm{M}\right),{ }^{4}$ however, hampers liberation of the target from the beads. An alternative to liberate the target is the use of a cleavable linker between the bait and biotin. ${ }^{5}$ This approach enables efficient elution of the target protein from the beads via the linker cleavage, but contamination owing to the presence of non-target proteins sometimes hampers identification of the target. ${ }^{6}$ The cleavage under mild conditions and generation of an orthogonal functional group not seen in proteins, therefore, has been desired in this procedure. The orthogonal functional group enables chemoselective labeling of the target protein by an isotopic or fluorescent tag. That facilitates discrimination of the target from contaminated proteins by MS using isotopic tag or SDS-PAGE using fluorescent tag.

We previously developed a traceable linker as an advanced cleavable linker that enables selective labeling of the target protein after elution from the streptavidin beads via the linker cleavage (Figure 1a). ${ }^{7,8}$ A key component of the traceable linker is a stimulus-responsive amino acid that possesses a stimulusremovable protective group (PG) on the phenolic hydroxyl group (Figure 1b). ${ }^{9}$ The stimulus-responsive amino acid induces amide 
bond cleavage after stimulus-induced removal of the PG and subsequent lactonization of a trimethyl lock moiety. ${ }^{10}$ In a previous report, the traceable linker composed of a thiolresponsive amino acid, in which the $\mathrm{PG}$ is a pnitrobenzenesulfonyl ( $p \mathrm{Ns}$ ) group, was presented (Figure 1a). The traceable linker was introduced onto an alkynylated protein by click chemistry and then adsorbed onto the streptavidin beads. Subsequent addition of a thiol triggered the cleavage of the linker to release the protein possessing an aminooxy group. Since the aminooxy group can react with an aldehyde chemoselectively, ${ }^{11}$ the eluted target protein was selectively labeled with an aldehyde-containing labeling reagent even when contaminated non-target proteins co-existed. As the thiol was used as the cleavage inducer in this system, it is preferable to remove endogenous thiols such as glutathione before the use of the thiolresponsive traceable linker. ${ }^{12}$ To avoid the risk of unintentional cleavage of the traceable linker, in this study, we have developed a fluoride-responsive (FR) traceable linker, because there are few fluoride ions present in a living body. ${ }^{13}$
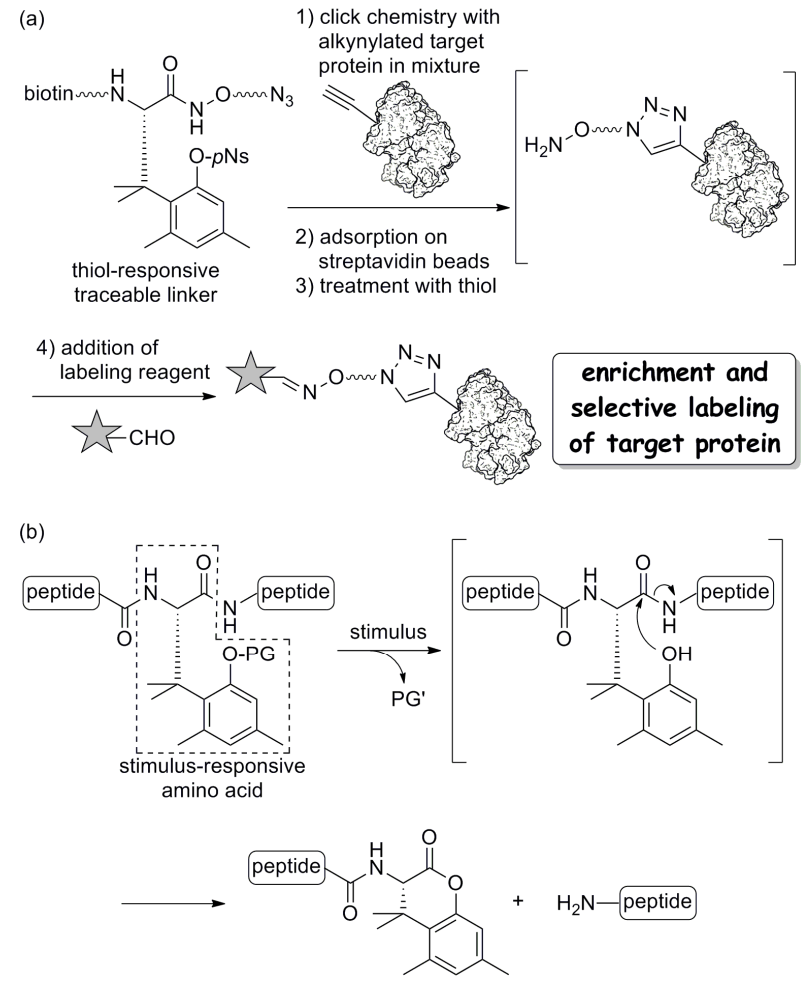

Figure 1. Molecular design. (a) Purification and selective labeling of an alkynylated protein using a thiol-responsive traceable linker ( $p$ Ns: $p$ nitrobenzenesulfonyl group). (b) A stimulus-responsive amide bond cleavage system (PG: protective group that is removable by appropriate stimulus).

\section{Results and discussion}

\subsection{Synthesis of a FR amino acid}

Preparation of the FR amino acid possessing a fluorideremovable protective group as the $\mathrm{PG}$ of the stimulus-responsive amino acid was attempted. A tert-butyldiphenylsilyl (TBDPS) group was chosen as the fluoride-removable PG because acid treatment is unavoidable for the synthesis of the traceable linker and the TBDPS group is relatively acid tolerant compared with other trisubstituted silyl protections. ${ }^{14}$ In this study, Fmoc protected derivatives were designed for Fmoc-based solid phase peptide synthesis (Fmoc SPPS). We first attempted to synthesize silyl ether 1, but introduction of the TBDPS group onto the phenolic hydroxyl group of $2^{15}$ did not proceed (Figure 2). In these reactions, recovery of the starting material, removal of the Boc group and/or removal of the tert-butyldimethylsilyl (TBS) group were observed. We speculated that the direct introduction of the TBDPS group onto the phenol is sterically unfavorable and steric crowding around the phenol was observed in an energy minimized structure of substrate 2 using an MM2 calculation (Figure S1). Therefore, preparation of $\mathbf{3}$ possessing a sterically less demanding siloxybenzyl unit, which can be removed via fluoride-induced cleavage of the silyl group followed by release of the quinone methide, onto the phenol was next examined (Scheme 1). ${ }^{16}$ Starting from phenol 2, it was subjected to the modified Mitsunobu reaction with the TBDPS derivative $\mathbf{4}^{17}$ using $N, N, N^{\prime}, N$ '-tetramethylazodicarboxamide (TMAD). ${ }^{18}$ The TBS group of $\mathbf{5}$ was then removed under acidic conditions to yield alcohol 6. After stepwise oxidation of the alcohol of $\mathbf{6}$, the Boc group was removed by the use of Ohfune's protocol, ${ }^{19}$ because cleavage of the $p$-siloxybenzyl group was observed when trifluoroacetic acid (TFA) or hydrogen chloride was employed. The obtained amine was finally protected with an Fmoc group to yield FR amino acid 3 .

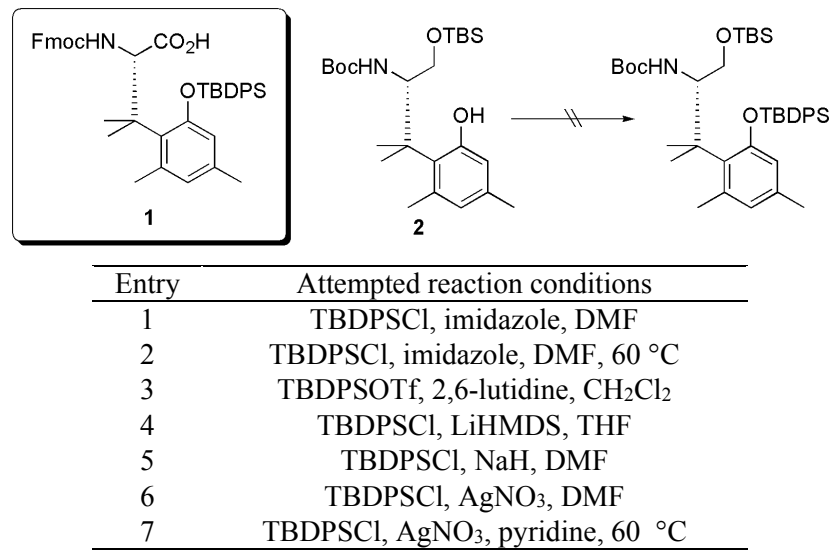

Figure 2. Synthetic attempts to prepare FR amino acid 1. (LiHMDS: lithium hexamethyldisilazide; trifluoromethanesulfonate) TBDPSOTf tert-butyldiphenylsilyl 


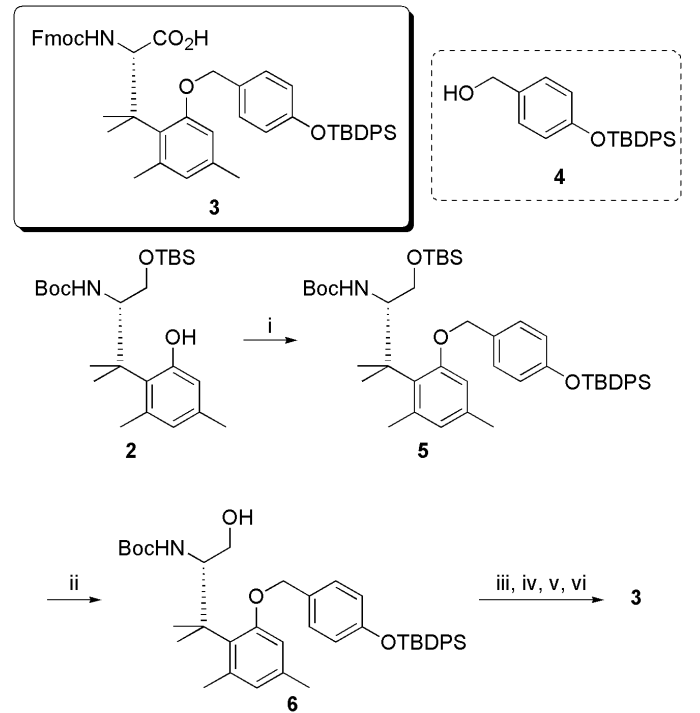

Scheme 1. Reagents and conditions: (i) 4, TMAD, $n-\mathrm{Bu}_{3} \mathrm{P}$, toluene, $98 \%$; (ii) $\mathrm{AcOH}$, THF, $\mathrm{H}_{2} \mathrm{O}$, quant.; (iii) oxalyl chloride, DMSO, $\mathrm{Et}_{3} \mathrm{~N}$, THF; (iv) $\mathrm{NaClO}_{2}, \mathrm{NaH}_{2} \mathrm{PO}_{4}, 2$-methyl-2-butene, tert- $\mathrm{BuOH}$, acetone, $\mathrm{H}_{2} \mathrm{O}$; (v) tertbutyldimethylsilyl trifluoromethanesulfonate (TBSOTf), 2,6-lutidine, $\mathrm{CH}_{2} \mathrm{Cl}_{2}$; (vi) FmocOSu, $\mathrm{Na}_{2} \mathrm{CO}_{3}$, acetonitrile $(\mathrm{MeCN}), \mathrm{H}_{2} \mathrm{O}, 43 \%$ (four steps).
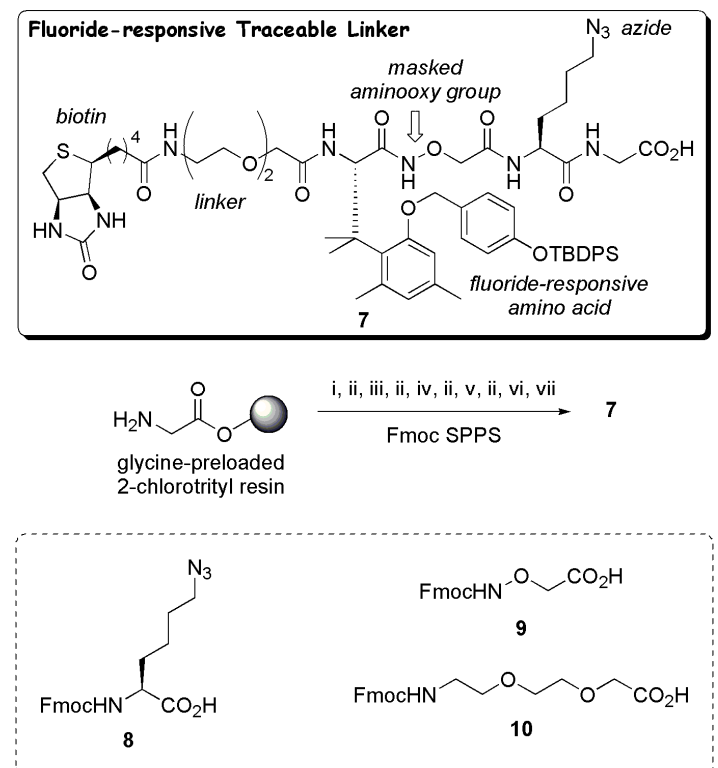

Scheme 2. Reagents and conditions: (i) 8, $\mathrm{HOBt} \cdot \mathrm{H}_{2} \mathrm{O}$, DIC, DMF; (ii) $20 \%$ (v/v) piperidine in DMF; (iii) 9, $\mathrm{HOBt} \cdot \mathrm{H}_{2} \mathrm{O}$, DIC, DMF; (iv) 3, HATU, DIEA, DMF; (v) 10, HOBt $\cdot \mathrm{H}_{2} \mathrm{O}$, DIC, DMF; (vi) biotin, $\mathrm{HOBt} \cdot \mathrm{H}_{2} \mathrm{O}$, DIC, DMF; (vii) $\mathrm{TFE} / \mathrm{AcOH} / \mathrm{CH}_{2} \mathrm{Cl}_{2}=1 / 1 / 3(\mathrm{v} / \mathrm{v})$.

\subsection{Preparation of a FR traceable linker}

FR traceable linker 7 was prepared using Fmoc SPPS (Scheme 2). Release of the linker from the resin using standard TFA conditions was not compatible because of acid lability of the siloxybenzyl unit. A 2-chlorotrityl resin from which the product can be released by treatment with a weak acid was therefore suitable for this synthesis and a commercially available amino acid-preloaded resin was employed to avoid laborious attachment of the first amino acid on the resin. Starting from the glycinepreloaded 2-chlorotrityl resin, azide derivative $\mathbf{8}^{20}$ and aminooxy derivative $\mathbf{9}^{21}$ were incorporated by standard Fmoc SPPS conditions using $N, N$ '-diisopropylcarbodiimide (DIC)/1hydroxybenzotriazole (HOBt) system. After coupling of FR amino acid 3 in the presence of $O$-(7-azabenzotriazol-1-yl)-
$N, N, N$ ', $N$ '-tetramethyluronium hexafluorophosphate (HATU) and $N, N$-diisopropylethylamine (DIEA), miniPEG unit $\mathbf{1 0}$ and biotin were incorporated using the DIC/HOBt system. The resin was finally treated with a 2,2,2-trifluoroethanol (TFE)/AcOH/ $/ \mathrm{CH}_{2} \mathrm{Cl}_{2}$ cocktail to generate FR traceable linker 7 without accompanying the deprotection of the siloxybenzyl unit $(12 \%$ all over yield. An HPLC chart of the product is shown in Figure S2 in the Supporting Information).

\subsection{Click chemistry, fluoride-induced cleavage, and selective labeling of the FR traceable linker with a model peptide}

In this study, alkyne-containing peptide $\mathbf{1 1}^{7}$ was employed as a model of the alkynylated target protein because of ease of handling and characterization of products (Figure 3). tert-Butanol was used as a cosolvent to dissolve the traceable linker. Traceable linker $\mathbf{7}$ and model peptide $\mathbf{1 1}$ in an aqueous tertbutanol solution were treated with $\mathrm{CuSO}_{4}$ and sodium ascorbate. Following a reaction time of $1 \mathrm{~h}$, completion of the coupling and production of conjugate $\mathbf{1 2}$ in high purity were confirmed by HPLC monitoring.

(a)

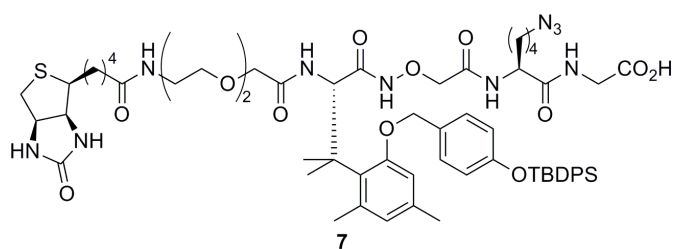

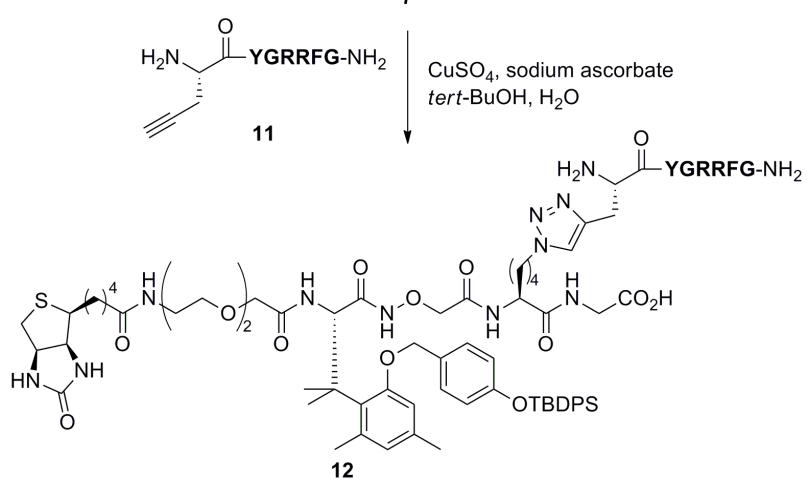

(b) before addition 12

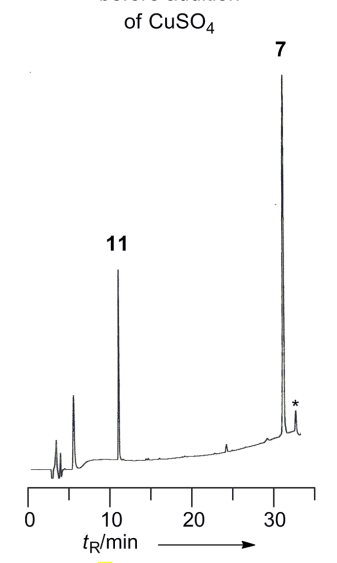

Figure 3. Click chemistry of the traceable linker. (a) Reaction of traceable linker 7 with model peptide 11. (b) HPLC monitoring of the click chemistry. HPLC conditions: Cosmosil $5 \mathrm{C}_{18}-\mathrm{AR}-\mathrm{II}$ analytical column, linear gradient of $0.1 \%(\mathrm{v} / \mathrm{v}) \mathrm{TFA} / \mathrm{MeCN}$ in $0.1 \%$ (v/v) TFA aq., 5-90\% over $30 \mathrm{~min}$. *Nonpeptidic compound. 
Fluoride-induced cleavage of the linker moiety of peptide conjugate 12 followed by the labeling reaction was next examined (Figure 4). Conjugate 12 was dissolved in a phosphate buffer containing $0.1 \mathrm{M} \mathrm{KF}, 100$ eq. of 2-mercaptoethanesulfonic acid sodium salt (MESNa) as a scavenger of quinone methide generated via removal of the siloxybenzyl unit, $6 \mathrm{M}$ guanidine hydrochloride, and $0.05 \mathrm{mM}$ EDTA (0.2 M phosphate, $\mathrm{pH}$ 7.6), and the reaction mixture was incubated at $37{ }^{\circ} \mathrm{C}$. The silyl group was completely removed after $2 \mathrm{~h}$ of the reaction. Following the additional $10 \mathrm{~h}$ of incubation, intermediate $\mathbf{1 3}$ was cleaved to generate biotin derivative 14 and aminooxy derivative 15. These results suggest that a rate determining step of the reaction is the removal of the quinone methide. The reaction mixture was then subjected to subsequent labeling without purification. We used 3bromobenzaldehyde as the labeling reagent, because the labeled compounds can easily be distinguished based on an isotope pattern of the MS. ${ }^{6 b, 22}$ To the reaction mixture was added 3bromobenzaldehyde and the labeling was accomplished within 5 min. Although 15 possesses a free amino group at the $\mathrm{N}$-terminus of the peptide, incorporation of two aldehydes was not observed. This result demonstrates that the selective labeling of the aminooxy group with the aldehyde was achieved. ${ }^{23}$

\section{\#\# Figure 4 \#\#}

\section{Conclusion}

Preparation of the FR amino acid and its application to the FR traceable linker were reported. The traceable linker was successfully introduced onto an alkyne-containing model peptide using click chemistry, and fluoride-induced cleavage followed by selective labeling of the obtained traceable linker-model peptide conjugate was achieved. Its application to the isolation and selective labeling of alkynylated target proteins is currently underway in our laboratory.

\section{Experimental section}

\subsection{General methods}

All reactions of small molecules were carried out under a positive pressure of argon at room temperature unless otherwise noted. For column chromatography, silica gel (KANTO KAGAKU N-60) was employed. Mass spectra were recorded on a Waters MICROMASS ${ }^{\circledR}$ LCT PREMIER $^{\mathrm{TM}}$ or a Bruker Esquire200T. NMR spectra were measured using a JEOL GSX400 or a JEOL GSX300 spectrometer. For HPLC separations, a Cosmosil 5 $\mathrm{C}_{18}$-AR-II analytical column (Nacalai Tesque, $4.6 \times 250 \mathrm{~mm}$, flow rate $1.0 \mathrm{~mL} / \mathrm{min}$ ) or a semipreparative column $(10 \times 250 \mathrm{~mm}$, flow rate $3 \mathrm{~mL} / \mathrm{min})$ was employed, and eluting products were detected by UV at $220 \mathrm{~nm}$. A solvent system consisting of $0.1 \%(\mathrm{v} / \mathrm{v})$ TFA in $\mathrm{H}_{2} \mathrm{O}$ (solvent A) and $0.1 \%$ TFA (v/v) in MeCN (solvent B) was used for HPLC elution. IR spectra and optical rotations were measured using a JASCO FT-IR 6200 and a JASCO P-2200 polarimeter (concentration in $\mathrm{g} / 100 \mathrm{~mL}$ ), respectively. A melting point was determined on a YAMATO-MODEL 20 melting point apparatus and was uncorrected. An elemental analysis was performed using a J-SCIENCE LAB JM10.

\subsection{Synthesis of FR amino acid derivatives}

4.2.1. (S)-tert-butyl [1-\{(tert-

butyldimethylsilyl)oxy\}-3-\{2-([4-\{(tertbutyldiphenylsilyl)oxy\}benzyl]oxy)-4,6dimethylphenyl\}-3-methylbutan-2-yl]carbamate (5)
To a stirred solution of phenol $2^{15}(200 \mathrm{mg}, 0.457 \mathrm{mmol})$, benzyl alcohol $4^{17}(250 \mathrm{mg}, 0.690 \mathrm{mmol})$ and TMAD $(236 \mathrm{mg}$, $1.37 \mathrm{mmol})$ in toluene $(4.6 \mathrm{~mL})$ was added tri- $n$-butylphosphine $(342 \mu \mathrm{L}, 1.37 \mathrm{mmol})$ at $0{ }^{\circ} \mathrm{C}$. After being stirred at same temperature for $30 \mathrm{~min}$, the resulting mixture was additionally stirred at room temperature for $3 \mathrm{~h}$. Following to the addition of water, the mixture was extracted with EtOAc. The organic layer was washed with brine, dried over $\mathrm{Na}_{2} \mathrm{SO}_{4}$, and concentrated in vacuo. The crude product was purified by column chromatography (hexanes/EtOAc $=20 / 1(\mathrm{v} / \mathrm{v})$ ) and $349 \mathrm{mg}$ of ether $5(0.446 \mathrm{mmol}, 98 \%)$ was obtained as a colorless oil: $[\alpha]^{20}$ -22.3 (c 1.29, $\left.\mathrm{CHCl}_{3}\right) ;{ }^{1} \mathrm{H} \mathrm{NMR}\left(\mathrm{CDCl}_{3}, 400 \mathrm{MHz}\right) \delta=-0.06$ $(3 \mathrm{H}, \mathrm{s}),-0.04(3 \mathrm{H}, \mathrm{s}), 0.86(9 \mathrm{H}, \mathrm{s}), 1.13(9 \mathrm{H}, \mathrm{s}), 1.40(9 \mathrm{H}, \mathrm{s})$, $1.49(3 \mathrm{H}, \mathrm{s}), 1.50(3 \mathrm{H}, \mathrm{s}), 2.20(3 \mathrm{H}, \mathrm{s}), 2.55(3 \mathrm{H}, \mathrm{s}), 3.47(1 \mathrm{H}, \mathrm{dd}$, $J=10.6$ and $5.0 \mathrm{~Hz}), 3.56(1 \mathrm{H}, \mathrm{dd}, J=10.6$ and $4.0 \mathrm{~Hz}), 4.54$ $(1 \mathrm{H}, \mathrm{ddd}, J=10.0,5.0$ and $4.0 \mathrm{~Hz}), 4.85(1 \mathrm{H}, \mathrm{d}, J=10.0 \mathrm{~Hz})$, $4.94(1 \mathrm{H}, \mathrm{d}, J=11.6 \mathrm{~Hz}), 4.99(1 \mathrm{H}, \mathrm{d}, J=11.6 \mathrm{~Hz}), 6.55(1 \mathrm{H}, \mathrm{s})$, $6.57(1 \mathrm{H}, \mathrm{s}), 6.78(2 \mathrm{H}, \mathrm{d}, J=8.5 \mathrm{~Hz}), 7.21(2 \mathrm{H}, \mathrm{d}, J=8.5 \mathrm{~Hz})$, 7.35-7.47 (6H, m), 7.71-7.77 (4H, m); ${ }^{13} \mathrm{C} \mathrm{NMR}\left(\mathrm{CDCl}_{3}, 75\right.$ MHz) $\delta=-5.6,-5.5,18.1,19.5,20.7,25.8,25.8,26.5,27.7,28.4$, $29.3,44.5,56.7,63.6,70.7,78.3,112.7,119.7,127.4,127.7$, $128.6,129.8,130.0,131.0,132.9,135.5,136.0,138.5,155.1$, 156.0, 158.7; IR (neat) 701, 835, 919, 1113, 1172, 1255, 1511, $1610,1700,1721,2858,2930,2957 \mathrm{~cm}^{-1}$; HRMS (ESI-TOF) $\mathrm{m} / \mathrm{z}$ calcd for $\mathrm{C}_{47} \mathrm{H}_{68} \mathrm{NO}_{5} \mathrm{Si}_{2}\left([\mathrm{M}+\mathrm{H}]^{+}\right)$782.4636, found 782.4610.

4.2.2. (S)-tert-butyl [3-\{2-([4-\{(tertbutyldiphenylsilyl)oxy benzyl] oxy)-4,6dimethylphenyl\}-1-hydroxy-3-methylbutan-2$y l]$ carbamate (6)

Glacial acetic acid $(6.0 \mathrm{~mL})$ and $\mathrm{H}_{2} \mathrm{O}(2.1 \mathrm{~mL})$ were added to a solution of silyl ether 5 (298 mg, $0.381 \mathrm{mmol})$ in THF $(2.1 \mathrm{~mL})$. The reaction mixture was stirred for $9 \mathrm{~h}$. After addition of water followed by extraction with EtOAc, the organic layer was washed with water and brine, dried over $\mathrm{Na}_{2} \mathrm{SO}_{4}$, and concentrated in vacuo. The crude product was purified by column chromatography (hexanes/EtOAc $=4 / 1$ then $2 / 1(\mathrm{v} / \mathrm{v}))$ and 258 $\mathrm{mg}$ of alcohol 6 (0.386 mmol, quant.) was obtained as a white amorphousness: $[\alpha]^{21} \mathrm{D}-6.10\left(\mathrm{c} 1.04, \mathrm{CHCl}_{3}\right) ;{ }^{1} \mathrm{H} \mathrm{NMR}\left(\mathrm{CDCl}_{3}\right.$, $400 \mathrm{MHz}) \delta=1.11(9 \mathrm{H}, \mathrm{s}), 1.36(9 \mathrm{H}, \mathrm{s}), 1.45(6 \mathrm{H}, \mathrm{s}), 2.20(3 \mathrm{H}$, s), $2.49(3 \mathrm{H}, \mathrm{s}), 3.45(1 \mathrm{H}, \mathrm{dd}, J=9.7$ and $7.8 \mathrm{~Hz}), 3.59(1 \mathrm{H}, \mathrm{d}, J$ $=9.7 \mathrm{~Hz}), 4.35(1 \mathrm{H}, \mathrm{dd}, J=8.5$ and $7.8 \mathrm{~Hz}), 4.89(1 \mathrm{H}, \mathrm{d}, J=$ $11.7 \mathrm{~Hz}), 4.93(1 \mathrm{H}, \mathrm{d}, J=11.7 \mathrm{~Hz}), 5.05(1 \mathrm{H}, \mathrm{d}, J=8.5 \mathrm{~Hz})$, $6.56(1 \mathrm{H}, \mathrm{s}), 6.60(1 \mathrm{H}, \mathrm{s}), 6.77(2 \mathrm{H}, \mathrm{d}, J=8.3 \mathrm{~Hz}), 7.17(2 \mathrm{H}, \mathrm{d}, J$ $=8.3 \mathrm{~Hz}), 7.34-7.46(6 \mathrm{H}, \mathrm{m}), 7.70-7.74(4 \mathrm{H}, \mathrm{m}) ;{ }^{13} \mathrm{C} \mathrm{NMR}$ $\left(\mathrm{CDCl}_{3}, 75 \mathrm{MHz}\right) \delta=19.4,20.7,25.9,26.5,28.3,29.2,43.5$, 59.4, 64.5, 70.9, 79.2, 112.6, 119.9, 127.6, 127.7, 129.1, 129.3, $129.9,130.3,132.8,135.5,136.4,138.3,155.4,157.3,158.5$; IR (KBr) 701, 823, 921, 1171, 1253, 1511, 1695, 2860, 2931, 2961 $\mathrm{cm}^{-1}$; HRMS (ESI-TOF) $\mathrm{m} / z$ calcd for $\mathrm{C}_{41} \mathrm{H}_{54} \mathrm{NO}_{5} \mathrm{Si}\left([\mathrm{M}+\mathrm{H}]^{+}\right)$ 668.3771, found 668.3797.

4.2.3. (S)-2-([\{(9H-fluoren-9-

yl) methoxy $\}$ carbonyl $]$ amino $)-3-\{2-([4-\{($ tert -

butyldiphenylsilyl)oxy\}benzyl]oxy)-4,6-

dimethylphenyl\}-3-methylbutanoic acid (3)

To a solution of oxalyl chloride $(38.0 \mu \mathrm{L}, 0.444 \mathrm{mmol})$ in $\mathrm{CH}_{2} \mathrm{Cl}_{2}(3.6 \mathrm{~mL})$ were added DMSO $(63.1 \mu \mathrm{L}, 0.888 \mathrm{mmol})$ and alcohol $6(198 \mathrm{mg}, 0.296 \mathrm{mmol})$ in $\mathrm{CH}_{2} \mathrm{Cl}_{2}(660 \mu \mathrm{L})$ slowly at $78{ }^{\circ} \mathrm{C}$, and the resulting solution was stirred at $-40^{\circ} \mathrm{C}$ for $30 \mathrm{~min}$. After addition of triethylamine $(206 \mu \mathrm{L}, 1.48 \mathrm{mmol})$ followed by stirring for $30 \mathrm{~min}$ at the same temperature, the reaction mixture was stirred at room temperature for an additional $30 \mathrm{~min}$. Then the reaction was quenched by the addition of water and the obtained mixture was extracted with $\mathrm{CH}_{2} \mathrm{Cl}_{2}$. The organic layer was washed with sat. $\mathrm{NH}_{4} \mathrm{Cl}$ aq., dried over $\mathrm{Na}_{2} \mathrm{SO}_{4}$, and concentrated in vacuo. To a solution of the crude product in 
acetone/tert $-\mathrm{BuOH} /$ water $(6 / 4 / 1(\mathrm{v} / \mathrm{v}), 10 \mathrm{~mL})$ were added 2methyl-2-butene ( $212 \mu \mathrm{L}, 2.00 \mathrm{mmol}), \mathrm{NaH}_{2} \mathrm{PO}_{4}$ (53.3 mg, 0.444 mmol) and $\mathrm{NaClO}_{2}(176 \mathrm{mg}, 1.55 \mathrm{mmol})$. The resulting mixture was stirred for $2.5 \mathrm{~h}$. Following to the addition of sat. $\mathrm{NH}_{4} \mathrm{Cl}$ aq., the mixture was extracted with EtOAc. The resulting organic layer was dried over $\mathrm{Na}_{2} \mathrm{SO}_{4}$ and concentrated in vacuo. To the crude product in $\mathrm{CH}_{2} \mathrm{Cl}_{2}(6.3 \mathrm{~mL})$ were added 2,6-lutidine (207 $\mu \mathrm{L}, 1.78 \mathrm{mmol})$ and TBSOTf $(272 \mu \mathrm{L}, 1.18 \mathrm{mmol})$, and the reaction mixture was stirred at room temperature for $2 \mathrm{~h}$. The resulting mixture was concentrated in vacuo, and the obtained residue was dissolved in $\mathrm{MeCN} / 10 \%$ (w/v) $\mathrm{Na}_{2} \mathrm{CO}_{3}$ aq. (3/1 (v/v), $6.3 \mathrm{~mL})$. To the resulting solution was added FmocOSu $(120 \mathrm{mg}$, $0.355 \mathrm{mmol}$ ), and the reaction mixture was stirred at room temperature overnight. After the addition of $5 \%(\mathrm{w} / \mathrm{v}) \mathrm{KHSO}_{4}$ aq., the mixture was extracted with diethyl ether. The obtained organic layer was washed with brine, dried over $\mathrm{Na}_{2} \mathrm{SO}_{4}$, and concentrated in vacuo. The crude material was purified by column chromatography $\left(\mathrm{CHCl}_{3}\right)$ and $103 \mathrm{mg}$ of Fmoc derivative $3(0.128 \mathrm{mmol}, 43 \%)$ was obtained as a beige amorphousness: $[\alpha]^{22}{ }_{\mathrm{D}}-5.58\left(c\right.$ 0.64, $\left.\mathrm{CHCl}_{3}\right) ;{ }^{1} \mathrm{H} \mathrm{NMR}\left(\mathrm{CDCl}_{3}, 400 \mathrm{MHz}\right) \delta=$ $1.06(9 \mathrm{H}, \mathrm{s}), 1.57(6 \mathrm{H}, \mathrm{s}), 2.15(3 \mathrm{H}, \mathrm{s}), 2.47(3 \mathrm{H}, \mathrm{s}), 4.05-4.13$ $(1 \mathrm{H}, \mathrm{m}), 4.15(1 \mathrm{H}, \mathrm{dd}, J=10.5$ and $6.8 \mathrm{~Hz}), 4.28(1 \mathrm{H}, \mathrm{dd}, J=$ 10.5 and $6.8 \mathrm{~Hz}), 4.93(2 \mathrm{H}, \mathrm{s}), 5.28(1 \mathrm{H}, \mathrm{d}, J=9.5 \mathrm{~Hz}), 5.56(1 \mathrm{H}$, $\mathrm{d}, J=9.5 \mathrm{~Hz}), 6.51(1 \mathrm{H}, \mathrm{s}), 6.57(1 \mathrm{H}, \mathrm{s}), 6.74(2 \mathrm{H}, \mathrm{d}, J=8.0 \mathrm{~Hz})$, $7.18(2 \mathrm{H}, \mathrm{d}, J=8.0 \mathrm{~Hz}), 7.20-7.44(10 \mathrm{H}, \mathrm{m}), 7.48(1 \mathrm{H}, \mathrm{d}, J=7.5$ $\mathrm{Hz}), 7.67(4 \mathrm{H}, \mathrm{d}, J=6.8 \mathrm{~Hz}), 7.70(2 \mathrm{H}, \mathrm{d}, J=7.5 \mathrm{~Hz}) ;{ }^{13} \mathrm{C}$ NMR $\left(\mathrm{CDCl}_{3}, 75 \mathrm{MHz}\right) \delta=19.4,20.8,25.7,26.5,28.3,28.8,44.1,47.1$, $60.2,66.8,70.7,112.5,119.8,119.9,119.9,125.1,125.1,127.0$, $127.6,127.7,128.3,129.0,129.4,129.8,132.8,135.5,136.9$, $137.9,141.2,143.9,155.3,156.0,158.5,175.6$; IR (KBr) 706, 742, 757, 823, 918, 1255, 1511, 1717, 2858, 2934, $3028 \mathrm{~cm}^{-1}$; HRMS (ESI-TOF) $\mathrm{m} / \mathrm{z}$ calcd for $\mathrm{C}_{51} \mathrm{H}_{53} \mathrm{NO}_{6} \mathrm{NaSi}\left([\mathrm{M}+\mathrm{Na}]^{+}\right)$ 826.3540 , found 826.3577 .

\subsection{Preparation of the FR traceable linker (7)}

The traceable linker was constructed on glycine preloaded 2chlorotrityl resin $(0.87 \mathrm{mmol}$ amine $/ \mathrm{g}, 20 \mathrm{mg}, 17 \mu \mathrm{mol})$. Coupling conditions for $\mathbf{8},{ }^{20} \mathbf{9},{ }^{21} \mathbf{1 0}$, and biotin: 3 eq. building block, 3 eq. DIC, and 3 eq. $\mathrm{HOBt} \cdot \mathrm{H}_{2} \mathrm{O}$ in DMF, $2 \mathrm{~h}$, room temperature. Coupling conditions for 3 : 1.2 eq. 3, 1.2 eq. HATU, 1.2 eq. DIEA in DMF (preactivated for $1 \mathrm{~min}$ ), $2 \mathrm{~h}$, room temperature. Removal of Fmoc group: $20 \%(\mathrm{v} / \mathrm{v})$ piperidine in DMF, 2 min first treatment followed by washing and subsequent second treatment for $8 \mathrm{~min}$, room temperature. Cleavage from resin $(20 \mathrm{mg})$ : TFE/ $\mathrm{AcOH} / \mathrm{CH}_{2} \mathrm{Cl}_{2}(1 / 1 / 3(\mathrm{v} / \mathrm{v})), 1 \mathrm{~mL}, 2 \mathrm{~h}$, room temperature. Work-up: After removal of solvent under vacuo, $\mathrm{MeCN} / \mathrm{H}_{2} \mathrm{O}(1 / 1(\mathrm{v} / \mathrm{v}))$ was added to the resulting mixture. Following the removal of the resin by filtration, the solution was subjected to HPLC purification to yield traceable linker 7 as a white lyophilized powder (2.6 mg, 12\%). Analytical HPLC conditions: linear gradient of solvent B in solvent A, 50 to $90 \%$ over $30 \mathrm{~min}$. Retention time $=24.3 \mathrm{~min}$. Semi-preparative HPLC conditions: linear gradient of solvent B in solvent A, 50 to $90 \%$ over $30 \mathrm{~min}$. LRMS (ESI-Ion Trap) $\mathrm{m} / \mathrm{z}$ calcd for $\mathrm{C}_{62} \mathrm{H}_{85} \mathrm{~N}_{10} \mathrm{O}_{13} \mathrm{SSi}\left([\mathrm{M}+\mathrm{H}]^{+}\right)$1237.6, found 1237.2.

\subsection{Click chemistry of traceable linker with model peptide (12)}

To a solution of traceable linker $7(0.1 \mu \mathrm{mol})$ and peptide $\mathbf{1 1}$ $(0.1 \mu \mathrm{mol})$ in $\mathrm{H}_{2} \mathrm{O} /$ tert $-\mathrm{BuOH}(1 / 1(\mathrm{v} / \mathrm{v}), 100 \mu \mathrm{L})$ were added $\mathrm{CuSO}_{4} \cdot \mathrm{H}_{2} \mathrm{O}(0.06 \mu \mathrm{mol})$ and sodium ascorbate $(0.5 \mu \mathrm{mol})$, and the reaction mixture was shaken at room temperature for $1 \mathrm{~h}$. Reaction progress was monitored by analytical HPLC. Analytical HPLC conditions: linear gradient of solvent B in solvent A, 5 to $90 \%$ over $30 \mathrm{~min}$. Conjugate 12: retention time $=23.1 \mathrm{~min}$. LRMS (ESI-Ion Trap) $\mathrm{m} / z$ calcd for $\mathrm{C}_{101} \mathrm{H}_{142} \mathrm{~N}_{24} \mathrm{O}_{21} \mathrm{SSi}([\mathrm{M}+$ $2 \mathrm{H}]^{2+}$ ) 1043.5 , found 1043.2.

\subsection{Fluoride-induced cleavage of the traceable linker followed} by labeling (13-16)

Peptide-traceable linker conjugate $12(0.1 \mu \mathrm{mol})$ in phosphate buffer containing $6 \mathrm{M}$ guanidine hydrochloride and $0.05 \mathrm{mM}$ EDTA (200 mM phosphate, $\mathrm{pH} 7.6,100 \mu \mathrm{L})$ was treated with $\mathrm{KF}$ $(10 \mu \mathrm{mol})$ and MESNa $(10 \mu \mathrm{mol})$. After incubation at $37^{\circ} \mathrm{C}$ for $12 \mathrm{~h}, 3$-bromobenzaldehyde $(0.1 \mu \mathrm{mol})$ was added to the reaction mixture. Progress of the reaction was monitored by HPLC. Analytical HPLC conditions: linear gradient of solvent B in solvent A, 5 to $90 \%$ over $30 \mathrm{~min}$. Intermediate 13: retention time $=16.5 \mathrm{~min}$, LRMS (ESI-Ion Trap) $\mathrm{m} / \mathrm{z}$ calcd for $\mathrm{C}_{85} \mathrm{H}_{123} \mathrm{~N}_{24} \mathrm{O}_{21} \mathrm{~S}$ $\left([\mathrm{M}+\mathrm{H}]^{+}\right)$1847.9, found 1847.3. Biotin derivative 14: retention time $=20.2 \mathrm{~min}$, LRMS (ESI-Ion Trap) $\mathrm{m} / \mathrm{z}$ calcd for $\mathrm{C}_{29} \mathrm{H}_{43} \mathrm{~N}_{4} \mathrm{O}_{7} \mathrm{~S}\left([\mathrm{M}+\mathrm{H}]^{+}\right)$591.3, found 591.1. Aminooxy derivative 15: retention time $=11.2 \mathrm{~min}$, LRMS $($ ESI-Ion Trap) $m / z$ calcd for $\mathrm{C}_{49} \mathrm{H}_{75} \mathrm{~N}_{20} \mathrm{O}_{13}\left([\mathrm{M}+\mathrm{H}]^{+}\right)$1151.6, found 1151.2. Labeled derivative 16: retention time $=15.4 \mathrm{~min}$, LRMS (ESIIon Trap) $m / z$ calcd for $\mathrm{C}_{56} \mathrm{H}_{78} \mathrm{BrN}_{20} \mathrm{O}_{13}\left([\mathrm{M}+\mathrm{H}]^{+}\right) 1317.5\left({ }^{71} \mathrm{Br}\right.$ derivative) and $1319.3\left({ }^{81} \mathrm{Br}\right.$ derivative), found 1317.1 and 1319.3.

\subsection{Preparation of siloxybenzyl chloride $\mathbf{1 7}$}

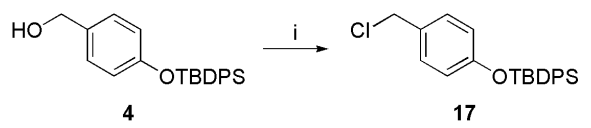

Scheme 3. Reagents and conditions: (i) $\mathrm{SOCl}_{2}, \mathrm{CH}_{2} \mathrm{Cl}_{2}, 70 \%$.

Thionyl chloride $(0.80 \mathrm{~mL}, 11 \mathrm{mmol})$ was slowly added to a solution of alcohol $4^{17}(2.0 \mathrm{~g}, 5.2 \mathrm{mmol})$ in $\mathrm{CH}_{2} \mathrm{Cl}_{2}(12 \mathrm{~mL})$ at $0{ }^{\circ} \mathrm{C}$, and the solution stirred for $2 \mathrm{~h}$ at room temperature. After the addition of ice, the reaction mixture was extracted with EtOAc. The organic layer was washed with saturated aqueous solution of $\mathrm{NaHCO}_{3}$ followed by brine, dried over $\mathrm{MgSO}_{4}$, and concentrated in vacuo. Chloride $\mathbf{1 7}$ was obtained as a white solid $(1.4 \mathrm{~g}, 70 \%)$ and was used without further purification. mp 77$79{ }^{\circ} \mathrm{C} ;{ }^{1} \mathrm{H} \mathrm{NMR}\left(\mathrm{CDCl}_{3}, 400 \mathrm{MHz}\right) \delta=1.09(9 \mathrm{H}, \mathrm{s}), 4.48(2 \mathrm{H}, \mathrm{s})$, $6.73(2 \mathrm{H}, \mathrm{d}, J=8.5 \mathrm{~Hz}), 7.11(2 \mathrm{H}, \mathrm{d}, J=8.5 \mathrm{~Hz}), 7.34-7.45(6 \mathrm{H}$, $\mathrm{m}), 7.68-7.72(4 \mathrm{H}, \mathrm{m}) ;{ }^{13} \mathrm{C} \mathrm{NMR}\left(\mathrm{CDCl}_{3}, 75 \mathrm{MHz}\right) \delta=19.4$, 26.2, 26.4, 46.2, 119.8, 127.8, 129.7, 129.9, 132.6, 135.4, 155.6; IR (KBr) 704, 919, 1115, 1258, 1510, 1605, 2858, 2932, 2960, $3070 \mathrm{~cm}^{-1}$; HRMS (ESI-TOF) $\mathrm{m} / \mathrm{z}$ calcd for $\mathrm{C}_{23} \mathrm{H}_{26} \mathrm{OSiCl}([\mathrm{M}+$ $\mathrm{H}]^{+}$) 381.1441, found 381.1457; Anal. calcd for $\mathrm{C}_{23} \mathrm{H}_{25} \mathrm{OSiCl}$ : C, 6.61; H, 72.51. Found: C, 6.63; H, 72.39.

\section{Acknowledgement}

This research was supported in part by PRESTO, Japan Science and Technology Agency (JST) and a Grant-in-Aid for Scientific Research (KAKENHI) including Innovative Areas "Fusion Material" and "ChemBioChem". Takeda Pharmaceutical Company and Astellas Foundation for Research on Metabolic Disorders are also acknowledged. JY and MD are grateful for JSPS fellowships. A propargyl glycine used in this study was a gift from Nagase \& Co., Ltd.

\section{References}

1. Recent reviews: (a) Lapinsky, D. J. Bioorg. Med. Chem. 2012, 20, 6237-6247; (b) Dubinsky, L.; Krom, B. P.; Meijler, M. M. Bioorg. Med. Chem. 2012, 20, 554-570; (c) Li, N.; Overkleeft, H. S.; Florea, B. I. Curr. Opin. Chem. Biol. 2012, 16, 227-233; (d) Wang, K.; Yang, T.; Wu, Q.; Zhao, X.; Nice, E. C.; Huang, C. Exp. Rev. Proteomics 2012, 9, 293-310; (e) Cravatt, B. F.; Wright, A. T.; Kozarich, J. W. Annu. Rev. Biochem. 2008, 77, 383-414. 
2. (a) Kotzyba-Hibert, F.; Kapfer, I.; Goeldner, M. Angew. Chem. Int. Ed. 1995, 34, 1296-1312; (b) Fleming, S. A. Tetrahedron 1995, 51, 12479-12520.

3. (a) Savage, M. D. BioMethods 1996, 7, 1-29; (b) Hofmann, K.; Kiso, Y. Proc. Natl. Acad. Sci. USA 1976, 73, 3516-3518.

4. Green, N. M. Adv. Protein Chem. 1975, 29, 85-133.

5. Recent reviews: (a) Bielski, R.; Witczak, Z. Chem. Rev. 2013 113, 2205-2243; (b) Leriche, G.; Chisholm, L.; Wagner, A. Bioorg. Med. Chem. 2012, 20, 571-582.

6. (a) Verhelst, S. H. L.; Fonovic, M.; Bogyo, M. Angew. Chem. Int. Ed. 2007, 46, 1284-1286; (b) Paulick, M. G.; Hart, K. M.; Brinner, K. M.; Tjandra, M.; Charych, D. H.; Zuckermann, R. N. J. Comb. Chem. 2006, 8, 417-426; (c) van der Veken, P.; Dirksen, E. H. C.; Ruijter, E.; Elgersma, R. C.; Heck, A. J. R.; Rijkers, D. T. S.; Slijper, M.; Liskamp, R. M. J. ChemBioChem 2005, 6, 2271-2280

7. Yamamoto, J.; Denda, M.; Maeda, N.; Kita, M.; Komiya, C.; Tanaka, T.; Nomura, W.; Tamamura, H.; Sato, Y.; Yamauchi, A.; Shigenaga, A.; Otaka, A. Org. Biomol. Chem. 2014, 12, 3821 3826.

8. Equlibrium-based hydrazone type linkers designed for purification and labeling of the target protein as similar to the traceable linker, see (a) Dirksen, A.; Yegneswaran, S.; Dawson, P. E. Angew. Chem. Int. Ed. 2010, 49, 2023-2027; (b) Park, K. D.; Liu, R.; Kohn, H. Chem. Biol. 2009, 16, 763-772.

9. (a) Shigenaga, A.; Ogura, K.; Hirakawa, H.; Yamamoto, J.; Ebisuno, K.; Miyamoto, L.; Ishizawa, K.; Tsuchiya, K.; Otaka, A ChemBioChem 2012, 13, 968-971; (b) Shigenaga, A.; Hirakawa, H.; Yamamoto, J.; Ogura, K.; Denda, M.; Yamaguchi, K.; Tsuji, D.; Itoh, K.; Otaka, A. Tetrahedron 2011, 67, 3984-3990; (c) Shigenaga, A.; Yamamoto, J.; Sumikawa, Y.; Furuta, T.; Otaka, A. Tetrahedron Lett. 2010, 51, 2868-2871; (d) Shigenaga, A.; Yamamoto, J.; Hirakawa, H.; Ogura, K.; Maeda, N.; Morishita, K.; Otaka, A. Tetrahedron Lett. 2010, 51, 2525-2528; (e) Shigenaga, A.; Tsuji, D.; Nishioka, N.; Tsuda, S.; Itoh, K.; Otaka, A. ChemBioChem 2007, 8, 1929-1931.

10. (a) Milstien, S.; Cohen, L. A. Proc. Natl. Acad. Sci. USA 1970, 67, 1143-1147; (b) Levine, M. N.; Raines, R. T. Chem. Sci. 2012, 3 2412-2420 and references therein.

11. Ulrich, S.; Boturyn, D.; Marra, A.; Renaudet, O.; Dumy, P. Chem. Eur. J. 2014, 20, 34-41.
12. (a) Anderson, E. Chem. Biol. Interact. 1998, 112, 1-14 and references therein; (b) Jones, D. P.; Carlson, J. L.; Samiec, P. S.; Sternberg, P.; Mody, V. C.; Reed, R. L.; Brown, L. A. S. Clin. Chim. Acta 1998, 275, 175-184

13. Itai, K.; Onoda, T.; Nohara, M.; Ohsawa, M.; Tanno, K.; Sato, T.; Kuribayashi, T.; Okayama, A. Clin. Chim. Acta 2010, 411, 263266 , and references therein.

14. Wuts, P. G. M.; Greene, T. W. Greene's Protective Group in Organic Synthesis, 4th Ed.; John Wiley \& Sons, Inc.: Hoboken, NJ, 2007.

15. Shigenaga, A.; Yamamoto, J.; Nishioka, N.; Otaka, A. Tetrahedron 2010, 66, 7367-7372.

16. A review of fluoride sensors including the use of the siloxybenzyl unit, see: Zhou, Y.; Zhang, J. F.; Yoon, J. Chem. Rev. in press (doi: $10.1021 / \mathrm{cr} 400352 \mathrm{~m}$ ).

17. Pettit, G. R.; Grealish, M. P.; Jung, M. K.; Hamel, E.; Pettit, R. K.; Chapuis, J.-C.; Schmit, J. M. J. Med. Chem. 2002, 45, 2534-2542.

18. Tsunoda, T.; Otsuka, J.; Yamamiya, Y.; Ito, S. Chem. Lett. 1994 23, 539-542.

19. Sakaitani, M.; Ohfune, Y. J. Org. Chem. 1990, 55, 870-876.

20. Katayama, H.; Hojo, H.; Ohira, T.; Nakahara, Y. Tetrahedron Lett. 2008, 49, 5492-5494.

21. Cipolla, L.; Rescigno, M.; Leone, A.; Peri, F.; Ferla, B. L.; Nicotra F. Bioorg. Med. Chem. 2002, 10, 1639-1646.

22. Recent examples of MS analyses utilizing isotope pattern of bromine: (a) Liu, H.; Lichti, C. F.; Mirfattah, B.; Frahm, J Nilsson, C. L. J. Proteome Res. 2013, 12, 4248-4254; (b) Hudson, S. R.; Chadbourne, F. L.; Helliwell, P. A.; Pflimlin, E.; ThomasOates, J. E.; Routledge, A. ACS Comb. Sci. 2012, 14, 97-100.

23. Peptide 11 was treated with KF, MESNa and 3bromobenzaldehyde in Na phosphate buffer ( $\mathrm{pH}$ 7.6) containing guanidine hydrochloride and EDTA, but no reaction was observed (Figure S3 in the Supporting Information). This result also supports that the aldehyde was incorporated onto the aminooxy group but not onto the amino group.

24. It was confirmed by co-injecting the reaction mixture of 4-(tertbutyldiphenylsiloxy)benzyl chloride 17 with KF and MESNa in phosphate buffer. Preparation of $\mathbf{1 7}$ is described in Scheme 3 of the experimental section. 
(a)<smiles>CCC(C)OCCNC(=O)[C@H]1SCC2NC(=O)N[C@H]21</smiles>

KF, MESNa, EDTA guanidine hydrochloride in phosphate buffer $(\mathrm{pH} 7.6)$<smiles>CC(=O)CC1SCC2NC(=O)NC21</smiles><smiles>C1CCCC1</smiles>

$\mathrm{H}_{2} \mathrm{~N} \stackrel{\mathrm{O}}{\Perp}$ YGRRFG-NH<smiles>CCC1CN=N1</smiles>

N-

4<smiles>C1CCC1</smiles>

$\mathrm{N} \sim \mathrm{CO}_{2} \mathrm{H}$

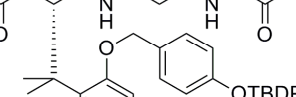<smiles>CCCc1cccc2c1OCC2</smiles>

(1)

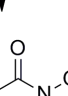

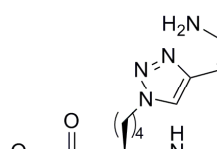<smiles>NCC(=O)OC=[14C]N</smiles>

(b)
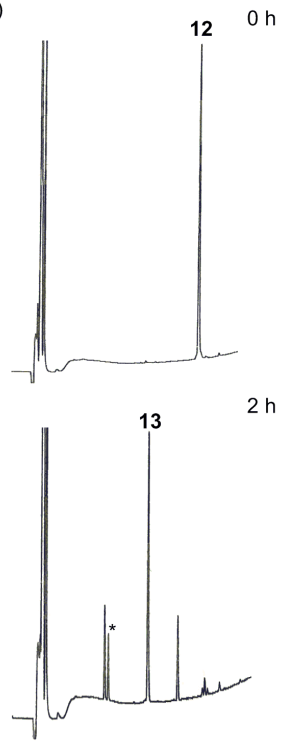<smiles>CCNC(=O)[C@H](C)C1SCC2NC(=O)NC21</smiles>

14

$\mathrm{H}_{2} \mathrm{~N} \stackrel{\mathrm{O}}{\Perp}$ YGRRFG-NH

$\mathrm{N}=\mathrm{N}$

$\mathrm{N}-$<smiles>C=C(NC(=O)CON)C(=O)CNCC</smiles><smiles>O=Cc1cccc(Br)c1</smiles><smiles>CCCc1cn(C=C(NC(=O)CO/N=C/c2cccc(Br)c2)C(=O)NCC(=O)O)nn1</smiles>

16
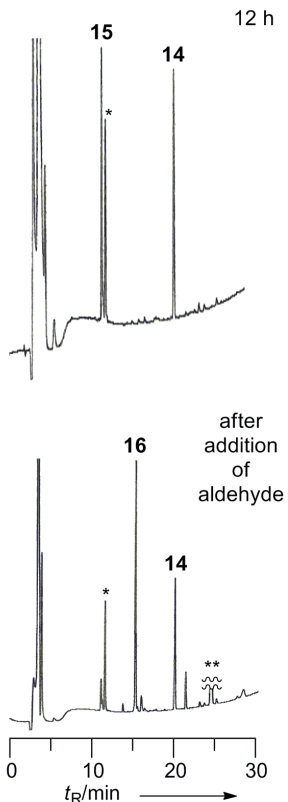

Figure 4. Fluoride-induced cleavage of the traceable linker followed by selective labeling. (a) Treatment of the traceable linker-peptide conjugate 12 with KF followed by labeling with 3-bromobenzaldehyde. (b) HPLC monitoring of the reactions. HPLC conditions: Cosmosil 5C 18 -AR-II analytical column, linear gradient of $0.1 \%(\mathrm{v} / \mathrm{v}) \mathrm{TFA} / \mathrm{MeCN}$ in $0.1 \%(\mathrm{v} / \mathrm{v})$ TFA aq., 5-90\% over 30 min. ${ }^{*}$ Non-peptidic compound derived from the quinone methide. ${ }^{24} * 3-$ Bromobenzaldehyde. 


\section{Graphical Abstract}

To create your abstract, type over the instructions in the template box below.

Fonts or abstract dimensions should not be changed or altered.

\section{Development of a fluoride-responsive amide bond cleavage device that is potentially applicable to a traceable linker}

Jun Yamamoto, Nami Maeda, Chiaki Komiya, Tomohiro Tanaka, Masaya Denda, Koji Ebisuno, Wataru Nomura, Hirokazu Tamamura, Youichi Sato, Aiko Yamauchi, Akira Shigenaga* and Akira Otaka*

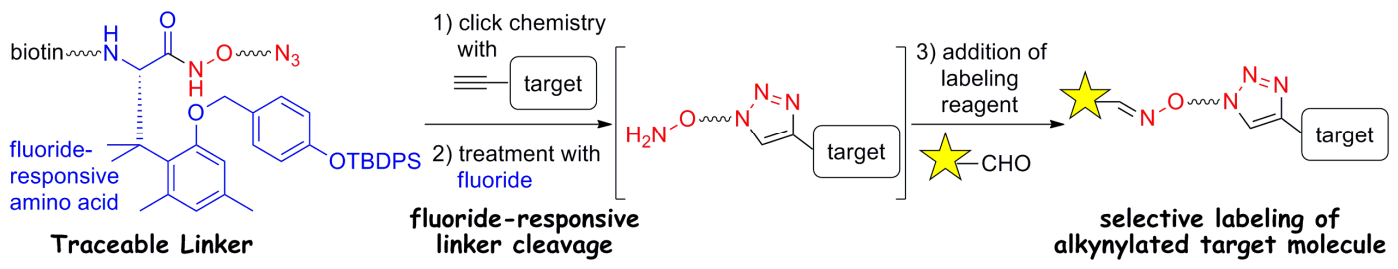

